
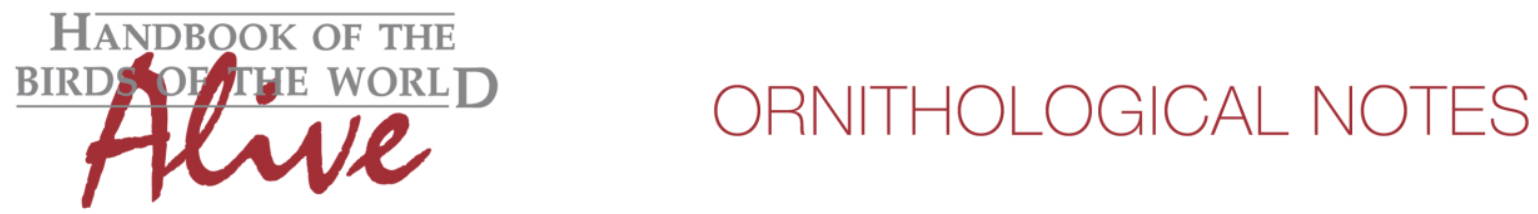

\title{
Notes on the vocalizations of Western Grasshopper-warbler (Locustella naevia)
}

Peter Boesman

In the following we briefly analyze and compare voice of the different races of Western Grasshopper-warbler (Locustella naevia). We also try to quantify the extent of any vocal differences using the criteria proposed by Tobias et al. (2010), as a support for taxonomic review. We have made use of sound recordings available on-line from Xeno Canto (XC).

Song is an insect-like constant reeling trill at a fairly high pitch.

Example of song (with a detailed time scale):

nominate

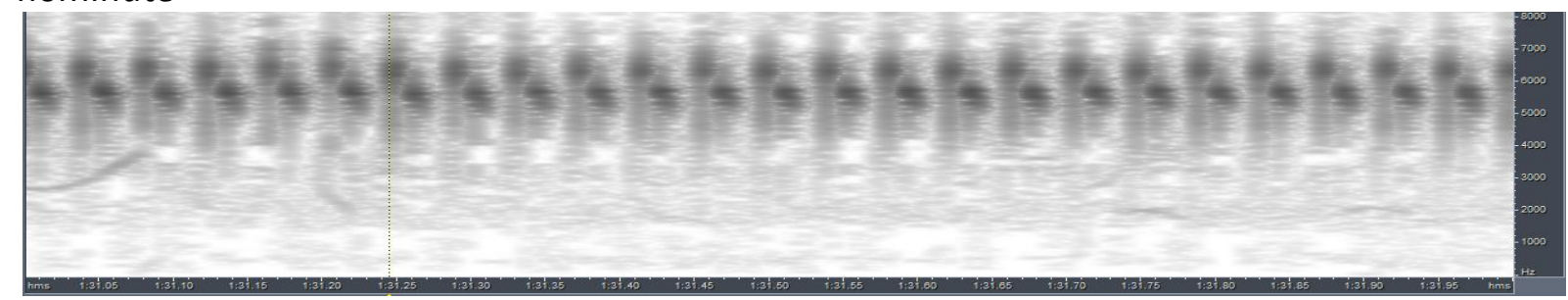

straminae

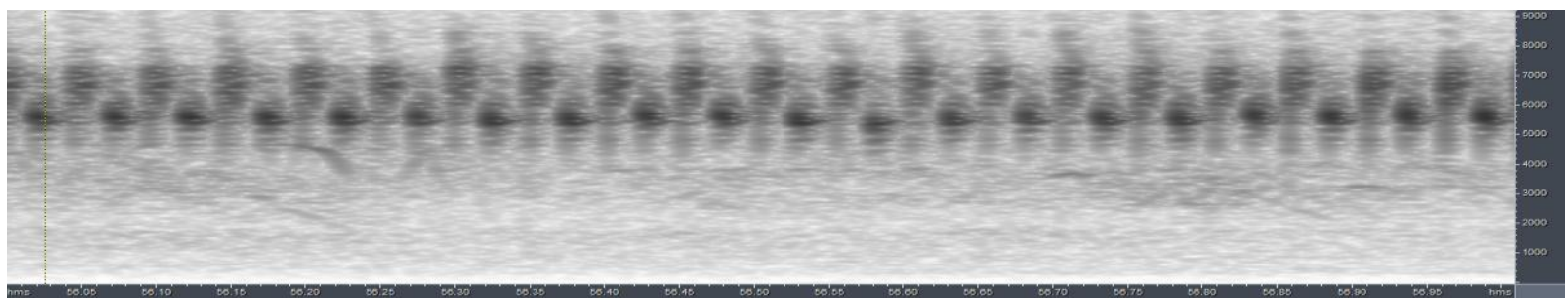

(We have not found recordings of races obscurior or mongolica).

Song of western and eastern races is very similar. There is however one single parameter which seems to be consistently different (!):

nominate (based on recordings all over Europe) $(n=9)$ : straminae (Kazakhstan/Uzbekhistan)( $\mathrm{n}=4)$ :

24-27 double notes per second

For comparison:

Lanceolated warbler Locustella lanceolata

20-21 double notes per second

c. 14-17 double notes/s, and different note shape

This pace seems to be very constant for every race. If this can be confirmed with more recordings of all races (only nominate is sufficiently documented at present), then by application of Tobias criteria this difference of pace could lead to a score of 3. 
This note was finalized on 12th February 2016, using sound recordings available on-line at that moment. We would like to thank in particular the many sound recordists who placed their recordings for this species on XC.

\section{References}

Tobias, J.A., Seddon, N., Spottiswoode, C.N., Pilgrim, J.D., Fishpool, L.D.C. \& Collar, N.J. (2010). Quantitative criteria for species delimitation. Ibis 152(4): 724-746.

\section{Recommended citation}

Boesman, P. (2016). Notes on the vocalizations of Western Grasshopper-warbler (Locustella naevia). HBW Alive Ornithological Note 235. In: Handbook of the Birds of the World Alive. Lynx Edicions, Barcelona. (retrieved from http://www.hbw.com/node/932198 on 29 September 2016). 